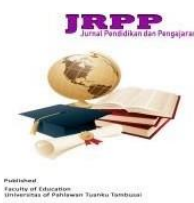

Zul Apriyanti ${ }^{1}$

Muhammad Syahrul

Rizal $^{2}$

Rusdial Marta ${ }^{3}$
Jurnal ReviewPendidikan dan Pengajaran

http://journal.universitaspahlawan.ac.id/index.php/jrpp

Volume 2 Nomor 2, Desember 2019

P-2655-710X e-ISSN 2655-6022
Submitted : 23/11/2019

Reviewed :28/11/2019

Accepted :10/12/2019

Published :28/12/2019

\section{PENERAPAN MODEL PEMBELAJARAN KOOPERATIF TIPE THINK PAIR AND SHARE UNTUK MENINGKATKAN AKTIVITAS BELAJAR IPA SISWA KELAS III SDN 004 BANGKINANG KOTA}

\begin{abstract}
Abstrak
Penelitian ini dilatar belakangi oleh rendahnya aktivitas belajar siswa pada mata pelajaran IPA di kelas III SDN 004 Bangkinang Kota Kecamatan Bangkinang Kota Kabupaten Kampar. Salah satu solusi untuk mengatasi masalah ini adalah dengan menggunakan model pembelajaran kooperatif tipe think pair and share. Dengan demikian tujuan penelitian ini adalah untuk mengetahui dan mendeskripsikan "model pembelajaran kooperatif tipe think pair and share untuk meningkatkan aktivitas belajar IPA pada siswa kelas III SD". Metode Penelitian ini menggunakan penelitian tindakan kelas (PTK) yang dilaksanakan sebanyak dua siklus dan setiap siklus dilaksanakan 2 kali pertemuan. Penelitian ini laksanakan pada SDN 004 Bangkinang Kota dengan subjek penelitian adalah kelas III SD. Pengumpulan data dalam penelitian ini menggunakan teknik observasi dan dokumentasi. Peningkatan aktivitas belajar siswa pada mata pelajaran IPA dari sebelum tindakan dengan rata-rata persentase $27,77 \%$, siklus I tergolong cukup dengan rata-rata persentase $47,77 \%$. Pada siklus II tergolong aktif dengan rata-rata $75,83 \%$. Jadi, pembelajaran IPA dengan model pembelajaran kooperatif tipe think pair and share dapat meningkatkan aktivitas belajar IPA siswa kelas III SDN 004 Bangkinang Kota.
\end{abstract}

Kata Kunci: Aktivitas Belajar, Tipe Think Pair And Share

\begin{abstract}
This research is motivated by the low learning activities of students in natural science subjects in class III SDN 004 Bangkinang Kota, Bangkinang District, Kampar Regency. One solution to overcome this problem is to use cooperative learning models think pair and share. Thus the purpose of this study is to find out and describe "think pair and share cooperative learning models to improve science learning activities in third grade elementary school students". Method This study uses classroom action research (CAR), which was carried out in two cycles and each cycle was held 2 meetings. This research was conducted at SDN 004 Bangkinang Kota with the subject of the study being grade III elementary school. Data collection in this study uses observation and documentation techniques. Increased student learning activities in science subjects from before the action with an average percentage of $27.77 \%$, the first cycle is quite sufficient with an average percentage of $47.77 \%$. In the second cycle classified as active with an average of $75.83 \%$. So, science learning with think pair and share type cooperative learning models can increase science learning activities of third grade students of SDN 004 Bangkinang Kota.
\end{abstract}

Keywords: Learning Activities, Think Pair And Share Types

\footnotetext{
${ }^{1}$ Pendidikan Guru Sekolah Dasar, Fakultas Ilmu Pendidikan (FIP), Universitas Pahlawan Tuanku Tambusai Alamat email zulapriyanti87@gmail.com

${ }^{2}$ Pendidikan Guru Sekolah Dasar, Fakultas Ilmu Pendidikan (FIP), Universitas Pahlawan Tuanku Tambusai Alamat email syahrul.rizal92@gmail.com

${ }^{3}$ Pendidikan Guru Sekolah Dasar, Fakultas Ilmu Pendidikan (FIP), Universitas Pahlawan Tuanku Tambusai Alamat email dial.fredo90@gmail.com
} 


\section{PENDAHULUAN}

Pendidikan merupakan suatu proses dalam rangka mempengaruhi peserta didik supaya mampu menyesuaikan diri sebaik mungkin dengan lingkungannya, dan dengan demikian akan menimbulkan perubahan dalam dirinya yang memungkinkannya untuk berfungsi dalam kehidupan masyarakat. Pengajaran bertugas mengarahkan proses ini agar sasaran dari perubahan itu dapat tercapai sebagaimana yang diinginkan.

Menurut Suriasumantri (Trianto, 2015: 136) Ilmu Pengetahuan Alam (IPA) merupakan bagian dari ilmu pengetahuan atau sains yang semula berasal dari bahasa inggris ,science ${ }^{e e}$. Kata „science $e^{\text {ee }}$ sendiri berasal dari kata dalam bahasa latin 'scientia' yang berarti saya tahu. ,science' terdiri dari social sciences (ilmu pengetahuan sosial) dan natural science (ilmu pengetahuan alam). Namun, dalam perkembangannya science sering diterjemahkan sebagai sains yang berarti ilmu pengetahuan alam (IPA) saja, walaupun pengertian ini kurang pas dan bertentangan dengan etimologi. Untuk itu, dalam hal ini kita tetap menggunakan istilah IPA untuk merujuk pada pengertian sains yang berarti natural science.

IPA di Sekolah Dasar (SD) bertujuan agar peserta didik memiliki kemampuan mengembangkan rasa ingin tahu, sikap positif dan kesadaran tentang adanya hubungan yang saling memperngaruhi antara lingkungan, teknologi dan masyarakat. Dari tujuan mata pelajaran IPA tersebut, siswa harus memahami beberapa aspek yang ada didalamnya, agar siswa dapat memahami konsep-konsep yang ada pada mata pelajaran IPA maka mata pelajaran IPA hendaknya diajarkan dengan cara yang tepat dan mencakup beberapa aspek seperti mengamati, mengklasifikasi, memprediksi dan mengkomunikasikan.

Mengingat pentingnya pembelajaran IPA, maka pembelajaran harus dilaksanakan secara maksimal. Keberhasilan kegiatan belajar mengajar sangat ditentukan oleh berbagai faktor yang berkaitan dengan proses belajar mengajar. Kunci utama dalam memajukan pendidikan adalah guru. Guru harus mampu menggunakan berbagai macam strategi pembelajaran agar proses pembelajaran lebih menarik dan menyenangkan.

Belajar sangat dibutuhkan adanya aktivitas, dikarenakan tanpa adanya aktivitas proses belajar tidak mungkin berlangsung dengan baik. Pada proses aktivitas pembelajaran harus melibatkan seluruh aspek siswa, baik jasmani maupun rohani sehingga perubahan perilakunya dapat berubah dengan cepat, tepat, mudah dan benar, baik berkaitan dengan aspek kognitif, afektif maupun psikomotor.

Agar proses pembelajaran IPA berjalan dengan baik di kelas dan dapat meningkatkan aktivitas belajar siswa seorang guru harus memiliki strategi tertentu agar pelaksanaan pembelajaran di kelas berjalan dengan lancar dan hasilnya optimal. Menurut Dierich dalam (Hamalik, 2013: 172), aktivitas belajar dapat diklasifikasikan menjadi delapan kelompok, yaitu: (1) visual activity, (2) oral activity, (3) writing activity, (4) drawing activity, (5) motor activity, (6) mental activity, (7) emosional activity, (8) listening activity. Untuk meningkatkan aktivitas siswa, diharapkan guru bisa memilih model pembelajaran agar siswa aktif serta belajar yang menyenangkan, karena model pembelajaran ini memberikan masalah yang nyata dalam kehidupan sehari-hari siswa.

Berdasarkan observasi yang di lakukan pada tanggal 2 Maret 2018 di SDN 004 Bangkinang Kota, terdapat permasalahan pada mata pelajaran IPA khususnya dikelas III SDN 004 Bangkinang Kota, bahwa masih dijumpai beberapa gejala-gejala yang menyebabkan rendahnya aktivitas belajar siswa terutama pada mata pelajaran IPA, seperti (1) guru hanya berfokus pada satu sumber buku paket atau satu informasi saja tidak melibatkan lingkungan dan menjadikan siswa tidak mendapatkan informasi yang banyak. (2) guru menggunakan metode yang kurang bervariatif dan inovatif, didominasi oleh metode konvensional (ceramah). Guru cenderung menyampakain meteri dari awal hingga akhir sehingga mengakibatkan siswa pasif dalam mengikuti pembelajaran dan terlihat jenuh karena hanya mendengarkan materi. (3) mengerjakan tugas, siswa tidak dapat bekerjasama dalam kelompok karena mereka tidak bisa diatur dan hanya bermain. (4) siswa lebih suka bekerja sendiri, padahal dengan berkelompok ilmu yang masuk dengan mengemukakan pendapat lebih banyak.

Hasil pengamatan di kelas III SDN 004 bangkinang kota menunjukkan gejala-gejala atau fenomena pada mata pelajaran IPA. Setelah dilakukan tes wawancara guru kelas III SDN 004 bangkinang kota dari 9 orang 
siswa hanya 3 orang yang aktif dalam pembelajaran IPA. Kurangnya motivasi dan minat belajar siswa yang mengakibatkan kurangnya peningkatan aktivitas belajar siswa, ditunjukkan dari 9 siswa yang tidak aktif dalam mata pelajaran IPA, yang mengakibatkan siswa tidak aktif: 1) siswa kurang membaca buku mata pelajaran, 2) siswa kurang aktif mengamati media, 3) siswa kurang inisiatif dalam belajar, kurang termotivasi, kurang aktif dan kurang bersemangat, khususnya mata pelajaran IPA, 4) siswa kurang aktif mengerjakan tugas yang diberikan oleh guru, 5) siswa kurang aktif berfikir dan memecahkan masalah.

Berdasarkan permasalahan tersebut penelitian ini dilaksanakan di kelas III SDN 004 bangkinang kota dengan pertimbangan: (1) aktivitas belajar siswa kelas III SDN 004 bangkinang kota dalam pembelajaran masih rendah. (2) kepala sekolah dan guru bersedia menerima masukan untuk perbaikan pembelajaran dan aktivitas siswa dalam proses pembelajaran. (3) pihak sekolah memberikan izin bagi peneliti untuk melakukan penelitian sekolah ini.

Oleh karena itu, perlu pemilihan model pembelajaran yang tepat untuk mengajarkan materi pelajaran IPA kepada siswa. Dari masalah di atas, terlihat rendahnya aktivitas belajar siswa. Hal ini butuh tindakan untuk memperbaiki keadaannya. Untuk itu dalam penelitian ini peneliti akan menerapkan model pembelajaran kooperatif tipe Think Pair and Share.

Model pembelajaran kooperatif tipe Think Pair and share ini memberikan kesempatan kepada siswa untuk saling berbagi informasi dengan teman-temannya baik dengan pasangannya sendiri maupun dengan pasangan lain. Melalui kegiatan diskusi, siswa dapat saling berbagi pengetahuan, menjalin interaksi antara sesama sehingga tidak ada lagi siswa yang pasif dalam proses pembelajaran.

Berdasarkan penjelasan di atas, peneliti termotivasi dan mendapat inspirasi untuk melakukan peningkatan pembelajaran dengan tindakan kelas yang berjudul: "Penerapan Model Pembelajaran Kooperatif Tipe Think Pair and Share untuk Meningkatkan Aktivitas Belajar IPA Siswa Sekolah Dasar".

\section{METODE}

Penelitian ini direncanakan terdiri dari dua siklus, masing-masing siklus dua kali pertemuan. Hal ini dimaksudkan agar siswa dan guru dapat beradaptasi dengan model pembelajaran yang diteliti. Sehingga hasil penelitian tindakan kelas dapat dimanfaatkan dalam proses belajar mengajar selanjutnya.

Adapun siklus PTK menurut Siwanto dan Suyanto (2017: 11-12) adalah sebagai berikut:

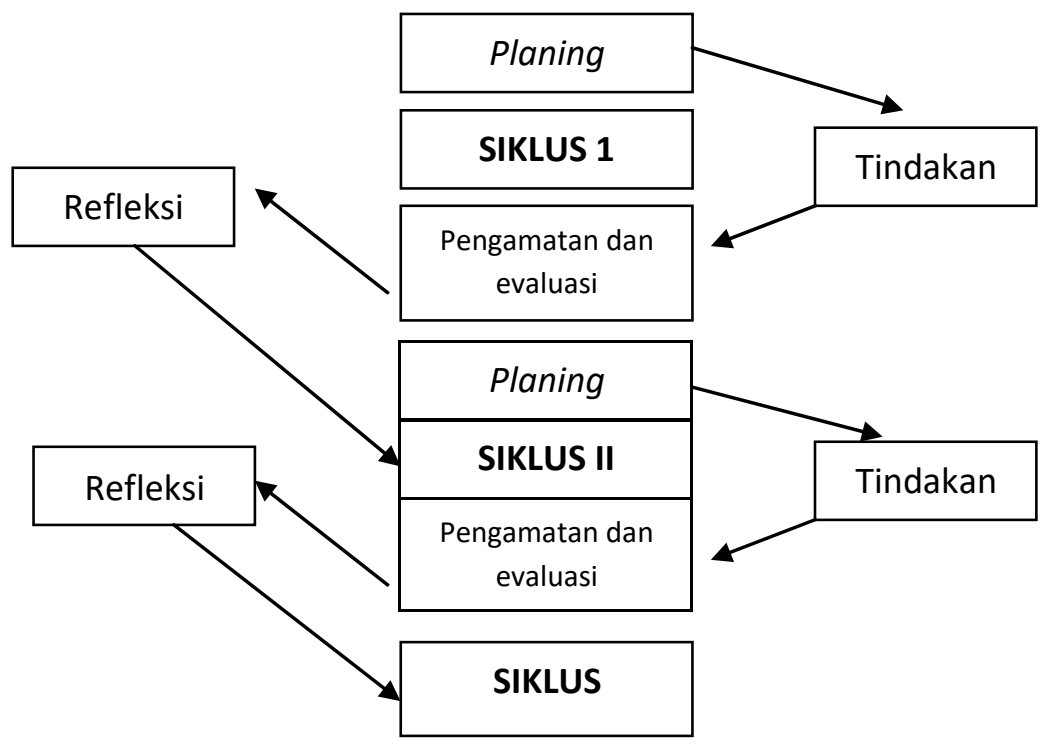

Gambar 1.2

Siklus PTK (Siswanto dan suyanto,2017: 11) 


\section{Perencanaan/Persiapan Tindakan}

Tahapan perencanaan atau persiapan tindakan ini, langkah-langkah yang dilakukan adalah sebagai berikut:

a) Penyusunan silabus pembelajaran.

b) Penyusunan Rencana Pelaksanaan Pembelajaran (RPP) berdasarkan penerapan model saat sekarang.

c) Menyiapkan lembar observasi.

d) Menunjuk teman sejawat untuk menjadi observer. Adapun tugas observer adalah untuk mengamati akivitas guru dalam proses pembelajaran Ilmu Pengetahuan Alam dengan penggunaan model Think Pair and Share.

\section{Tindakan (action)}

Langkah-langkah pembelajaran dengan penerapan model kooperatif tipe Think Pair and Share.

\section{Obeservasi}

Observasi (pengamatan) dilaksanakan selama penelitian berlangsung. Kegiatan observasi meliputi pengamatan terhadap pelaksanaan pembelajaran, mencatat apa saja kegiatan yang dilakukan siswa dikelas dan melihat apa saja yang menjadi hambatan saat pembelajaran berlangsung.

\section{Refleksi}

Pada tahap ini, peneliti menganalisis kekurangan dan kelebihan dari rancangan yang telah dilaksanakan. Apabila terdapat kekurangan, maka akan dijadikan sebagai bahan untuk membuat rancangan selanjutnya, sehingga tujuan pembelajaran tercapai sesuai dengan yang diinginkan. Refleksi dilakukan secara kolaboratif, yaitu adanya diskusi terhadap berbagai masalah yang terjadi dikelas penelitian.

\section{Teknik Analisis Data}

Setelah data terkumpul selanjutnya adalah menganalisisnya. Dalam penelitian ini ada data yang bersifat kualitatif dan kuantitatif. Untuk menganalisis data yang diperoleh melalui observasi dan dokumentasi, maka peneliti menggunakan teknik analisa kualitatif. Penelitian kualitatif adalah jenis penelitian yang menghasilkan penemuan-penemuan yang tidak dapat dicapai dengan menggunakan prosedur-prosedur statistik.

Data kuantitatif dalam penelitian ini digunakan untuk mengukur aktivitas belajar siswa. Aktivitas belajar terdiri dari kreativitas secara individu dari presentase aktivitas siswa. Setelah data terkumpulkan melalui observasi dan dokumentasi, data aktivitas siswa diolah dengan menggunakan rumus prensentase, yaitu sebagai berikut:

$$
\mathrm{P}=\frac{\mathrm{F}}{\mathrm{N}} \mathrm{X} 100 \%
$$

\section{Keterangan:}

$\mathrm{F} \quad=$ Frekuensi yang sedang dicari presentasenya

$\mathrm{N} \quad=$ Frekuensi/jumlah banyaknya individu

$\mathrm{P} \quad=$ Angka prensentase

100 = Bilangan tetap

Dalam menentukan kriteria penilaian tentang hasil penelitian, maka dilakukan pengelompokkan atas 5 kriteria penelitian yanitu baik sekali, baik, cukup, kurang sekali. Adapun criteria persentase tersebut yaitu sebagai berikut:

Tabel 1.3 kriteria Penggolongan Aktivitas Belajar Siswa

\begin{tabular}{|c|c|c|}
\hline NO & $\begin{array}{c}\text { Skor Rata-rata } \\
\text { Aktivitas Belajar }\end{array}$ & kategori \\
\hline 1 & $80 \%-100 \%$ & Baik sekali \\
\hline 2 & $70 \%-79 \%$ & Baik \\
\hline 3 & $60 \%-69 \%$ & Cukup \\
\hline 4 & $50 \%-59 \%$ & Kurang \\
\hline 5 & $0 \%-49 \%$ & Sangat kurang \\
\hline
\end{tabular}

Sumber: Arikunto (Yusnita, 2017:29) 


\section{HASIL DAN PEMBAHASAN}

\section{Perencanaan Pembelajaran Bahasa Indonesia dengan Menggunakan Media Gambar}

Pada perencanaan siklus I dan siklus II pembelajaran Bahasa Indonesia dengan materi tema organ gerak manusia dan hewan, pada siswa kelas V SDN 004 Langgini Bangkinang Kota, peneliti harus menyiapkan perencanaan pembelajaram karena proses pembelajaran perlu direncanakan, adapun perencanaan yang dilakukan oleh peneliti dalam peneliti ini yaitu: menyusun instrumen berupa silabus, menyusun RPP dengan menggunakan media gambar, menyiapkan lembar observasi aktivitas guru dan siswa, Lembar Tugas Siswa, menerima guru kelas V menjadi Observer siswa, dan meminta teman sejawat untuk menjadi observer siswa.

Adapun komponen-komponen penting yang ada dalam rencana pembelajaran meliputi: identitas, standar kompentensi (KD), indikator, tujuan pembelajaran, materi pokok, pembelajaran dengan menggunakan media gambar, langkah-langkah pembelajaran, sumber pembelajaran, dan penilaian. Standar kompetensi pembelajarannya adalah Menentukan ide pokok bacaan, menulis dan mengembangkan ide pokok menjadi paragraf.

Pada siklus I, setelah melalui proses perencanaan pembelajaran hingga terlaksana pembelajaran di kelas dengan menggunakan media gambar untuk meningkatkan keterampilan menulis karangan siswa. Jika menulis karangan siswa belum terlaksana dengan baik maka perlu perencanaan yang lebih baik pada siklus II.

Jadi, setelah dilaksanakan tindakan dengan menggunakan media gambar dan diamati oleh observer siklus I, maka penelitian akan menyiapkan perencanaan pembelajaran pada siklus II sehingga tujuan dari menulis karangan dapat tercapai. Sebelum melaksanakan tindakan, peneliti akan menyiapkan gambar untuk memberikan apersepsi pada siswa yang sesuai dengan materi yang sedang diajarkan dan mudah dipahami oleh siswa. Kemudian memisahkan letak bahan ajar, lembar tugas siswa dan gambar sehingga ketika masuk kelas peneliti sudah siap untuk mengajar.

\section{Proses Pembelajaran Bahasa Indonesia dengan Menggunakan Media Gambar}

Berdasarkan hasil pelaksanaan pada siklus I, pembelajaran masih tergolong rendah kerana saat guru memberikan apersepsi siswa kurang antusias dan tidak fokus pada gambar, dalam menyampaikan motivasi dan tujuan pembelajaran siswa masih ada yang bercerita dengan teman sebangkunya dan tidak mendengarkan. Begitu juga siswa yang memperlihatkan kemampuannya walaupun suka bercerita tapi berusaha untuk bertanya sesuai perintah guru. Menurut Kusnandi dan Sujtipto (2013:41-42) media gambar adalah media yang berfungsi untuk menyampaikan pesan melalui gambar yang menyangkut indera penglihatan. Pesan yang disampaikan dituangkan melalui simbol-simbol komunikasi visual. Media gambar mempunyai tujuan untuk menarik perhatian memperjelaskan materi, menghilustrasikan fakta dan informasi. Jika diberi kesempatan untuk mengembangkan sendiri, masih ada siswa yang bercerita karena sebelumnya belum terbiasa merumuskan pertanyaan sehingga sistematik yang akan dibentuk tidak berjalan dengan lancar.

Selain kelemahan itu yang didapatkan dari siswa, maka pendidikpun berperan penting dlam suksesnya sesuatu pembelajaran. Ini terjadi katika guru kurang membimbing siswa dlam membaca wacana sehingga ada siswa yang membaca keras dan ada yang membaca dalam hati. 
Dalam mengajar guru belum membimbing siswa seperti apa pembelajaran yang sedang berlangsung. Karena siswa itu adalah hal baru dan berbeda dari pembelajaran sebelumnya. Menurut Rahmawatiningsih (2010:5) menyatakan bahwa dengan menggunakan media gambar dapat membantu menyajikan suatu kejadian peristiwa yang kronologis dengan menghadirkan orang, benda, dan latar. Kronologis atau urutan peristiwa dapat memudahkan siswa untuk menuangkan idenya dalam kegiatan bercerita. Jadi, pada siklus I guru belum menggunakan media gambar ini dengan baik sehingga diperbaikan pada siklus II dengan pembimbing siswa bagaimana proses pembelajaran yang akan terjadi. Dengan kurangnya bimbingan guru tentang proses pembelajaran yang sehingga juga berpengaruh pada pengelolaan kelas yang masih kurang sehingga proses pembelajaran menggunakan media gambar masih belum berjalan dengan semestinya.

Pada siklus II ini sudah terlaksana dengan baik, karena siswa sudah bisa melaksanakan pembelajaran sesuai dengan cara kerja menggunakan media gambar, siswa telah memperhatikan dan mendengarkan tujuan pembelajaran yang disampaikan oleh guru. Siswa mendengarkan penjelasan yang di sampaiakn oleh guru sehingga siswa memahami dan aktif dalam belajar, siswa dengan mudah mengerjakan tugas yang diberikan oleh guru. Guru telah mengatur waktu dengan baik, sehingga dapat membimbing siswa untuk menyimpulkan pembelajaran secara keseluruhan. Dengan penguasaan kelas yang baik maka mempengaruhi hasil keterampilan menulis karangan siswa yang ditandai dengan siswa sudah sangat baik dalam mengemukakakan ide dalam menulis karangan, sistem penulisan siswa sudah benar, karangannya tidak bertele-tele lagi, penggunaan bahasanya juga sudah baik dan dalam memilih judul karangan juga sudah tepat sesuai dengan gambar yang diamati oleh siswa.

Berdasarkan hasil pelaksanaan pada siklus I dan siklus II, dapat dinyatakan bahwa pembelajaran di kelas V SDN 004 Langgini Bangkinang Kota menggunakan media gambar dapat meningkatkan keterampilan menulis karangan siswa kelas V SDN 004 Langgini Bangkinang Kota.

\section{Peningkatan Keterampilan Menulis Karangan Siswa dengan Menggunakan Media Gambar}

Dari hasil kegiatan selama penelitian dengan menggunakan media gambar memiliki kelemahan dan kelebihan masing-masing yang tercipta dari proses pembelajaran yang sedang berlangsung. Karena dipengaruhi oleh pengelolaan kelas yang dilakukan guru. Karena siswa yang awalnya hanya sabagai pendengar dan sekarang dihadapkan pada situasi untuk mengajak mengarang sebuah karangan sendiri sehingga membutuhkan proses untuk berubah. Maka proses keterampilan menulis karangan oleh Abbas (2006:125) tentang kemampuan mengungkapkan gagasan, pendapat dan perasaan pada pihak lain dengan melalui bahasa tulis. Pada siklus I ini ada 9 orang siswa dengan persentase 52\%. Kemudian pada siklus II peneliti mempelajari apa kelemahan pada siklus I karena pada pengelolaan kelas masih kurang dan masih banyak siswa yang belum fokus. Sehingga pada siklus II siswa yang tuntas ada 14 orang siswa yang dengan persentase $82 \%$.

Peningkatan proses belajar siswa dari keseluruhan pada siklus I yaitu $71,76 \%$ siswa yang sudah tuntas dalam keterampilan menulis karangan. Pada siklus I ini ada 9 orang siswa yaitu AT, AD, GF, FR, FJ, QS, ID, dan MI. Jika dilihat dari hasil proses belajar siswa pada siklus I proses belajar siswa masih tergolong rendah, hal ini disebababkan karena pada siklus I masih banyak siswa yang tidak memperhatikan dan mendengar tujuan pembelajaran yang disampaikan

Jurnal Review Pendidikan dan Pengajaran (JRPP) 
oleh guru, tingkat keaktifan siswa masih kurang, maka dari kekurangan-kekurangan tersebut harus diperbaiki agar tidak terjadi pada siklus selanjutnya, perbaikan ini harus dilakukan dengan cara guru harus membuat siswa tertarik dengan pembelajarn yang diajarkan oleh guru agar meningkatkan keaktifan siswa saat belajar.

Hasil perolehan hasil belajar siswa pada siklus II mengalami peningkatan jika dibandingkan dengan sikls I. Siswa yang aktif secara keseluruhan yaitu $80,94 \%$. Siswa yang tuntas dalam keterampilan menulis karangan pada pertemuan siklus II ada 14 orang siswa yaitu AT, AF, CT, GF, FR, FJ, FR, QS, ID, KR, MH, NB, dan Melsya. Hasil proses belajar siswa telah mencapai indikator keberhasilan yaitu $80 \%$. Dengan demikian dapat disimpulkan bahwa proses belajar siswa mengalami peningkatan dengan menggunakan media gambar. Jadi, hasil analisis ini mendukung hipotesis tindakan yang diajukan yaitu "Peningkatan Keterampilan Menulis karangan Dengan Menggunakan Media Gambar Pada Siswa Kelas V SDN 004 Langgini Bangkinang Kota.

\section{SIMPULAN}

\section{A. Simpulan}

Berdasarkan hasil dan pembahasan, maka dapat disimpulkan:"melalui model pembelajaran kooperatif tipe Think Pair and Share dapat meningkatkan aktivitas bealajar siswa pada mata pelajaran IPA kelas III SDN 004 Bangkinang Kota. Peningkatan aktivitas belajar siswa pada siklus 1 adalah $47,77 \%$ dengan kategori cukup aktif, meningkatkan pada siklus II menjadi $78,04 \%$ dengan kategori aktif pada siklus II.

\section{B. Implikasi}

Pembelajaran penggolongan hewan sedernahan dengan penerapan model pembelajaran kooperatif tipe Think Pair and Share dapat dijadikan sebagai bahan acuan untuk mengadakan penelitian selanjutkan dari sudut permasalahan yang berbeda.Selain itu dapat diimplementasikan sebagai bahan kajian pendekatan pembelajaran bagi guru untuk diterapkan di SDN 004 Bangkinang Kota sebagai alternatif model pembelajaran menggolongkan makhluk hidup sederhana.

Berdasarkan hasil penelitian dan kesimpulan, maka peneliti sampaikan beberapa implikasi sebagai berikut: bagi siswa, penerapan model pembelajaran kooperatif tipe Think Pair and Share ternyata mampu meningkatkan aktivitas belajar. Oleh karena itu dalam upaya meningkatkan aktivitas belajar siswa model pembelajaran kooperatif tipe Think Pair and Share bisa dikembangkan dalam proses pembelajaran. Bagi guru model pembelajaran kooperatif tipe Think Pair and Share dalam kegiatan pembelajaran penggolongan hewan sederhana bisa dijadikan alternative pilihan agar pelaksanakankegiatan siswa salam pembelajarn penggolongan hewan sederhana dapat dilakukan dengan baik dan mandiri perlu ditunjang dengan beberapa sumber belajar lainnya yang dapat dijadikan pedoman dalam kegiatan pembalajaran.

Oleh karena itu pihak sekolah pro aktif menfasilitasi segala kebutuhan guru dan siswa dalam upaya meningkatkan mutu layanan pendidikan dan bagi peneliti sendiri agar lebih banyak lagi memberikan pembelajaran kepada para siswa dengan varian model pembelajaeran yang mampu meningkatkan minat dan semangat siswa untuk belajar 


\section{DAFTAR PUSTAKA}

Abbas, S. (2006). Pembelajaran Bahasa Indonesia Yang Efekti Di Sekolah Dasar. Jakarta: Departemen Pendidikan Nasional.

Ananda, R. (2018). Peningkatan Pembelajaran PKn dengan Penerapan Metode Role-Playing Siswa Kelas II SDN 003 Bangkinang Kota. Jurnal Basicedu Volume 2 Nomor 1 Tahun 2018 Halaman 37.

Arsyad. (2016). Media Pembelajaran. Jakarta: PT Rajagrafindo Persada.

Astuti, Y. (2013). Peningkatan Keterampilan Menulis Karangan Narasi Menggunakan Model Experiential Learning Pada Siswa Kelas IV SDN Bangunjiwo Bantul. Universitas Negeri Yogyakarta: Skripsi tidak dipublikasikan.

Azlina. (2016). Peningkatan Keterampilan Menulis Karangan Narasi dengan Menggunakan Pendekatan CTL Siswa Sekolah Dasar. Bangkinang: Skripsi Tidak Dipublikasikan.

Azmussya"ni. (2014). Peningkatan Keterampilan Menulis Menggunakan Peningkatan Proses Dengan Media Gambar di SDN 3 Sakra. Jurnal Prima Edukasia, Volume 2- Nomor 1,2014 .

Ahsin, M.N. (2016) Peningkatan Keterampilan Menulis Karangan Narasi Dengan Menggunakan Media Audiovisual dan Metode Quantum Learning. Jurnal Refleksi Edukatika. Vol. 6 No. 2 Juni 2016.

Faizah, H. (2011). Menulis Karangan Ilmiah. Pekanbaru: Cendikia Insani.

Gie, TL. (2002). Pengantar dunia karang-mengarang. Yogyakarta: Liberty Yoyakarta.

Hamdani. (2011). Strategi Belajar Mengajar. Bandung: Pustaka Setia.

Hernawan, dkk. (2007). Media Pembelajaran Sekolah Dasar. Bandung: UPI PRESS.

Isneani, Nur Faizah. (2013). Penggunaan Media Kartu Bilangan Untuk Meningkatkan Motivasi Belajar Siswa. [Online]. Tersedia: http://lib.unnes.ac.id/1734/1401409066.pdf.[Diakses 20 maret 2018].

Juldianty. (2016). Peningkatan Keterampilan Menulis Narasi Melalui Penggunaan Media Gambar Seri Siswa Kelas III. Jurnal Pendidikan Dasar Volume 7 Edisi 2 Desember 2016

Keraf, G. (1994). Kompisisi. Jakarta: Nusa Indah.

Kusnandi, C. dan Sujtipto, B. (2013). Media Pembelajaran Manual dan Digital. Bogor: Ghalia Indonesia.

Lestari, G. (2014). Upaya Meningkatkan Kemampuan Mengarang Siswa Melalui Media Gambar Seri. Yogyakarta: Skripsi tidak dipublikasikan.

Mawarni, Rosdiana. (2015) Peningkatan Keterampilan Menulis Karangan Narasi Menggunakan Media Film Siswa Kelas III SDN Pencar 2, Selemen. Jurnal Pendidikan Guru Sekolah Dasar Edisi 15 Tahun ke IV Agustus 2015.

Mayer, RE. (2009). Mutimedia Prinsip-Prinsip dan Aplikasi. Yogyakarta: Pustaka Pelajar.

Mariana. (2017). Peningkatan Keterampilan Menulis Paragraf Melalui Penerapan Kegiatan Menulis Jurnal dan Pemanfaatnya Pada Siswa Kelas III MTS Negeri Kota Tering Tinggi. SEJ Volume 7 No. 1 Juni 2017.

Marta, R. (2018). Penerapan Model Kooperatif tipe Nominal Group untuk Meningkatkan Hasil Belajar Matematika di Kelas IV Sekolah Dasar. Jurnal Basicedu Volume 2 Nomor 1 Tahun 2018 Halaman 82.

Nurdin dan Adriantoni. (2016). Kurikulum dan Pembelajaran. Jakarta: Rajawali.

Nugraheni. (2012). Pengajaran Bahasa Indonesia Berbasis Karakter. Yogyakarta. Mentari Pustaka.

Rahardi, K. (2009). Bahasa Indonesia Untuk Perguruan Tinggi. Bandung: Erlangga.

Rahmawatiningsih, (2010). Media peendidikan. Jakarta: PT. Raja Grafindo Pustaka.

Syarif, dkk. (2009). Metodologi Penelitian Pendidikan. Jakarta: Pt Bumi Aksara.

Saputra dan Rudhyanto, (2005). Pembelajaran kooperatif untuk meningkatkan keterampilan anak TK. Jakarta: Depdiknas.

Sirait, dkk. (1985). Pedoman karang-mengarang. Jakarta: pusat pembinaan

Syah, M. (2005). Psikologi Belajar. Jakarta: Bumi Aksara. 
Siswanto dan Suyanto, (2017). Metode Peneleitian Kombinasi Kualitatif dan Kuantitatif Pada Penelitian Tindakan (PTK Dan PTS). Klaten: Bossscript.

Suprihatiningrum, J. (2016). Strategi Pembelajaran. Jogjakarta: Ar-Ruzz Media. Sudjana, N dan Rivai, A. (2013). Media Pembelajaran. Bandung: Sinar Baru Algensindo.

Sundayana, R. (2014). Media dan Alat Peraga Dalam Pembelajaran Matematika. Bandung: Alfabeta.

Saddhono, (2012). Meningkatkan Keterampilan Berbahasa Indonesia. Bandung: Karya Putra Darwai

Taufina, (2016). Mozaik Keterampilan Berbahasa di Sekolah Dasar. Bandung: CV Angkasa

Tarigan. (2008). Menulis Sebagai Suatu Keterampilan Berbahasa. Bandung: Angkasa.

Triyanto. (2007). Model Pembelajaran Terpadu dalam Teori dan Praktek. Jakarta : Tim Prestasi Pustaka.

Warsidi. 2009. Mengenal jenis Tulisan. Bandung: Putri Delcon.

Yulianti, R. (2016). Peningkatan Keterampilan Menulis Karangan Narasi Menggunakan Media Pop-Up Book Pada Siswa Kelas IV SD Negeri 2 Kedunglegok Kecamatan Kemangkon Kabupaten Purbalingga Tahun Ajaran 2015/2016. Universitas Negeri Yogyakarata: Skripsi tidak dipubikasikan.

Yusnita, E. (2017). Peningkatan Aktifitas Belajar Matematika dengan Menggunakan Pendekatan Scientific di Kelas IV Siswa Sekolah Dasar. Universitas Pahlawan Tuanku Tambusai Bangkinang: Skripsi tidak dipuplikasikan. 